\title{
Kuprava Clay Deposit Research Comparison
}

\author{
Valentina Puzule \\ Faculty of Engineering \\ Rezekne Academy of Technologies \\ Rezekne, Latvia \\ valentina.puzule@hotmail.com
}

\author{
Gotfrids Noviks \\ Faculty of Engineering \\ Rezekne Academy of Technologies \\ Rezekne, Latvia \\ gotfrids.noviks@rta.lv
}

\begin{abstract}
Clay minerals and their structures are extensively studied in the world, both from the point of view of geological research and material science. The aim of the research is to identify and summarize the resources of the Kuprava clay deposit, their placement in the field and selective extraction possibilities. Total clay resources in the Kuprava area are significantly more than 16 million $\mathrm{m}^{3}$. The clays are located in several uneven layers with relatively different characteristics. Until now, clay has been studied in separate layers for the production of bricks and high quality lightweight expanded clay aggregate (LECA).

The work is based on using and comparing the geological survey data of 1951 to 1992, the latest laboratory test data, as well as the technical documentation of the former Kuprava factory. The study also includes a review of two recent studies of the composition of Kuprava Member clay. New eco-innovative composite materials require clay with a fully defined composition and properties. Clay extraction must be selective - on separate layers, so that the use can be accurately determined by the research. Cartographic material has also been added to accurately locate each of the four fields studied.
\end{abstract}

Keywords-adsorption, clay, clay deposits, Kuprava.

\section{INTRODUCTION}

The aim of the study is to identify and compare the clay resources of the Upper Devonian Famennian stage Katlesi formation Kuprava member, their placement at the deposit and the possibilities of extraction.

Both clay and lime kilns have operated in the vicinity of Kuprava, but they are long closed.

Kuprava clay deposit is one of the most important clay deposits in Latvia (see Fig. 1). The stocks of clay studied at Kuprava deposit reach 16 million $\mathrm{m}^{3}$, yet together with resources forecasted around the deposit it amounts to several billions $\mathrm{m}^{3}[1]$.

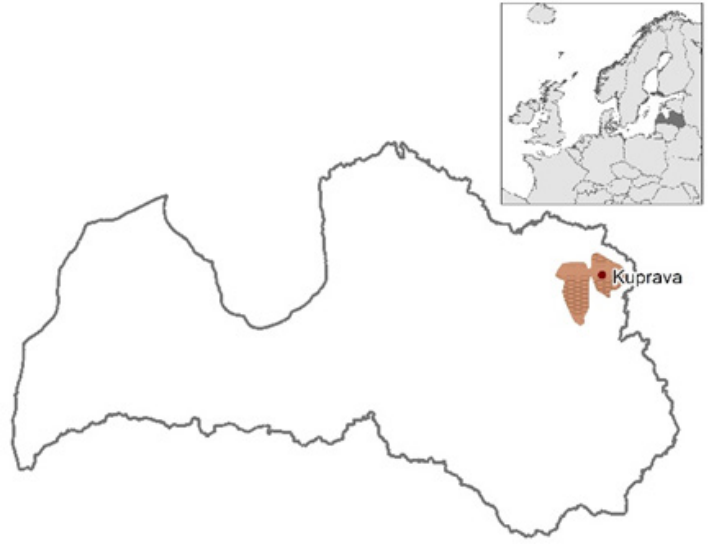

Fig. 1. Location of Kuprava clay deposit.

First details on the production of clay bricks are related to the needs of Vilaka church. Vilaka church was built in Gothic style from red bricks made at the Bronti site [2].

According to data from Sorokin [3], Katlesi formation Kuprava member consists of brick-red, cherry-red or mottled clays with interlayers of siltstone and domerite. From the thick clay layer its upper and lower parts are formed by clay, but in the middle traceable layer of sand can be found, the thickness of which changes slightly due to sedimentogenic creep processes at the time of its formation [3]. During the period of 1951-1992, a detailed geological survey has been carried out in 4 clay sites (see Fig. 2)

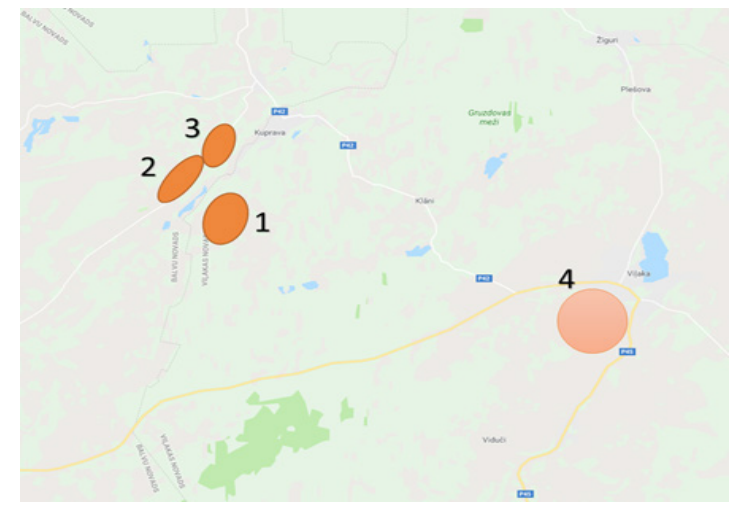

Fig. 2. Schematic map of geological exploration sites: 1 - Kuprava clay quarry and its adjacent area; 2 - Mednieki clay deposit; 3 Veckuprava (Kuprava clay field); 4 - Vilaka deposit. 
Clay extraction at industrial scale took place only at the current Kuprava clay quarry (see Fig. 2, 1 site). No newer studies have been carried out and no information on them can be found in databases.

\section{Materials AND METHODS}

The survey of geological studies and drilling sites took place after the conversion of survey specific coordinates to the current maps.

Rock samples were collected, and their composition analysis was carried out.

The rock samples were dried to an air-dry state, crushed in a mortar till powder consistency. Element analysis was performed by using XRF method with X-ray fluorescence spectrometer Bruker AXS S4 PIONEER. Phase detection was performed by using XRD method with X-ray diffractometer Bruker AXS D8 ADVANCE.

Samples of dolomite, white clay and red clay from various clay deposits in Kuprava member were analyzed separately.

To determine the adsorption capacity of clay Methylene Blue method was used [4], [5].

Relationship of the optical density in Methylene Blue solution depending on the concentration of Methylene Blue in the ranges of $20-100 \mathrm{mg} / \mathrm{l}$ and $100-700 \mathrm{mg} / \mathrm{l}$ was experimentally measured with spectrophotometer at wavelength of $400 \mathrm{~nm}$. For measurements of Clay adsorption capacity Methylene Blue standard solution with a concentration of $1 \mathrm{~g} / \mathrm{l}$ was prepared. Clay samples were dried and crushed. For measurements $1 \mathrm{~g}$ of corresponding Clay was poured into flask, $50 \mathrm{ml}$ of Methylene Blue standard solution were filled in, and that was subject to mixing for 30 minutes. Afterwards suspension was centrifuged, and samples were taken to determine the optical density of suspension in cuvettes in $1 \mathrm{~cm}$ deep solution layer.

Methylene Blue concentration in those solutions that were exposed to adsorption was than determined using calibration curves for the corresponding ranges. Clay adsorption capacity - was than calculated using the following formula.

$$
A d=\frac{\left(C_{0}-C_{1}\right) V}{m}
$$

Results in (1) are in $\mathrm{mg} / \mathrm{g}$, where $\mathrm{C}_{0}$ - initial MB concentration $(1000 \mathrm{mg} / \mathrm{l}), \mathrm{C}_{1}$ - Methylene Blue concentration after adsorption in $\mathrm{mg} / \mathrm{l}, \mathrm{V}$ - volume of solution $(50 \mathrm{ml}), \mathrm{m}$ - mass of Clay sample $(1 \mathrm{~g})$. Results and discussion

Kuprava member clay has similar rock stratification in all four areas studied by geologists.

The most thorough clay studies were at Kuprava clay quarry, where Katlesi formation clay part makes up almost all the cut with a thickness of 40-65 m. Studies were carried out at Gailava and Irikava villages [6], [7], [8], [9]. Here, several layers of clay are distinguished, which have been tested for use in the production building materials such as brick and expanded clay (LECA).

In the Mednieki clay deposit [10], studies were conducted on average to a depth of $6 \mathrm{~m}$, and stocks were calculated according to them, but in the Zenchenko study [6], wells were made and clay layers found up to 20.70 m deep. In Veckuprava according to Zenchenko's studies, useful clay layers were found up to $12 \mathrm{~m}$ depth; During the search for white burning clay, Jurevics [11] drilled holes up to $20 \mathrm{~m}$.

According to Zenchenko's research [6], there may be several small mining sites in the Vilaka deposit, but no large prospective areas have been identified. Soil layers, aleirolite or dolomite layers usually form so-called empty rocks at the sides of the deposit.

In the Kuprava clay deposit, the top layer of soil formed during the Quaternary period is relatively thin an average of $30 \mathrm{~cm}$. In some places a thicker layer of moraine, consisting of loam, has been preserved.

Clay mining is hampered by the hard rock layer beneath the Quaternary rocks. The Kuprava clay deposit is partly covered by $0.5-1.5 \mathrm{~m}$ thick dolomite, dolomite sandstone layers that impede access to quality clay. To remove this layer, blasting must be done [9].

So far, dolomite residues have collapsed in large pits at the edge of the quarry. During the slope processes, they slip into the clay quarry, mix with clay, creating a burden for clay mining. Dolomites that have not been removed or moved at a sufficient distance during quarrying make slippery slopes (see Fig. 3).

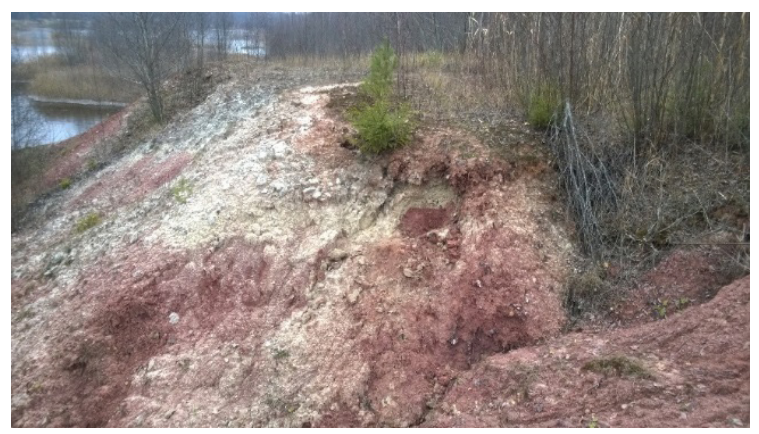

Fig. 3. Dolomite landslips in the Kuprava quarry wall.

The Dolomite layer in the Kuprava neighborhood below the Quaternary rocks is not evenly distributed. In places where agricultural land has been installed, the dolomite layer has been partially removed and used for production lime [12]. For example, dolomites in the neighborhood of Oknupe were taken to the Miezaji lime burner. However, in some places it is still exposed to the ground and is well visible after field cultivation (Veckuprava).

The Kuprava quarry in the western section according to Jonins research [9] consists of territories that are covered with dolomite and are therefore not recommended for clay quarrying.

The chemical composition of the dolomites was 
determined in the southern part of the Kuprava quarry, compared to the dolomite of the Murava deposit used for lime burning [12]. The composition shows that there is more silicon and potassium in comparison to classic dolomite (see Fig. 4).

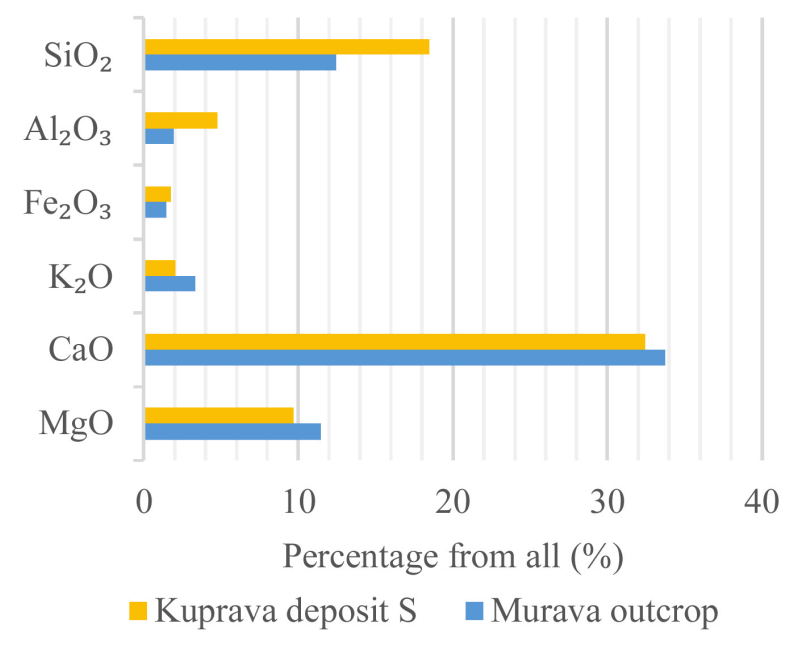

Fig. 4. Comparison of dolomite composition.

The X-ray diagram shows that dolomite, including calcite, quartz, muscovite and orthoclase, dominate in these rocks. By composition and structure, it can be called sandy dolomite, although geological wells are marked as fossilized sandstone (see Fig. 5)

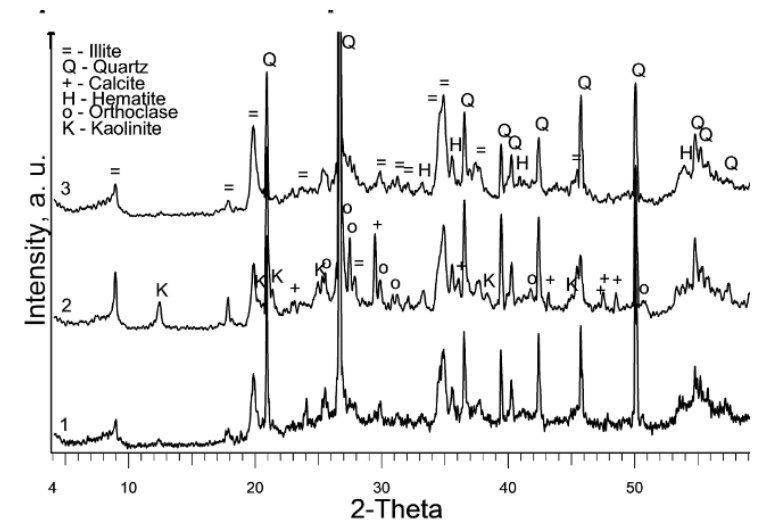

Fig. 5. X-ray diagram of clay composition Kuprava Clay Region: 1 . Kupravas district. 2 Mednieki deposit, 3 - Quarry South section

Under the dolocrates, there is a layer of light aleirolite that is not usable for leaning the clay and gives a mottled color to the ceramic products.

The Kuprava clay deposit is laid in several uneven layers. The layers of the Katleši formation consist mainly of bluish, red, and colored clay.

The composition of the blue clay is compared to the two deposits on the left and right bank of Bolupe River. A comparison of the most common elements is given in the Fig. 6.

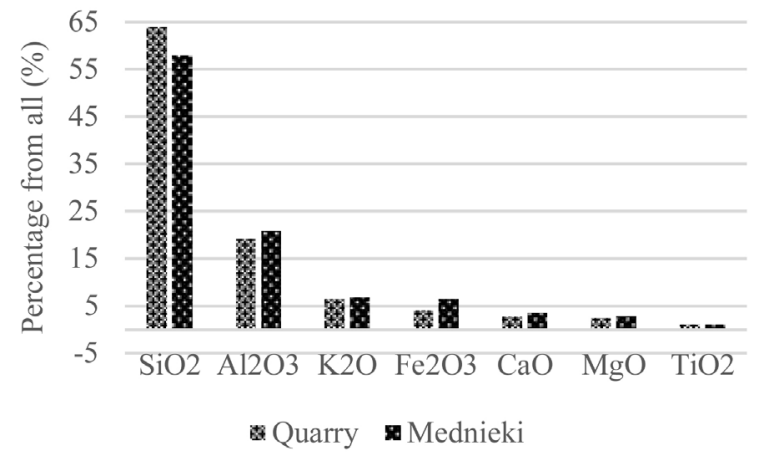

Fig. 6. Comparison of blue clay composition.

The composition of the phases also has similar results - the clay part is made up of illite, quartz, orthoclase, as well as kaolinite and calcium carbonate in the Kuprava district.

In turn, dolomite curves are more pronounced in the Mednieki deposit. The composition of the red clay is compared to all four fields, two sampling sites have been selected for the Kuprava quarry - in the south and west section (see Fig. 7).

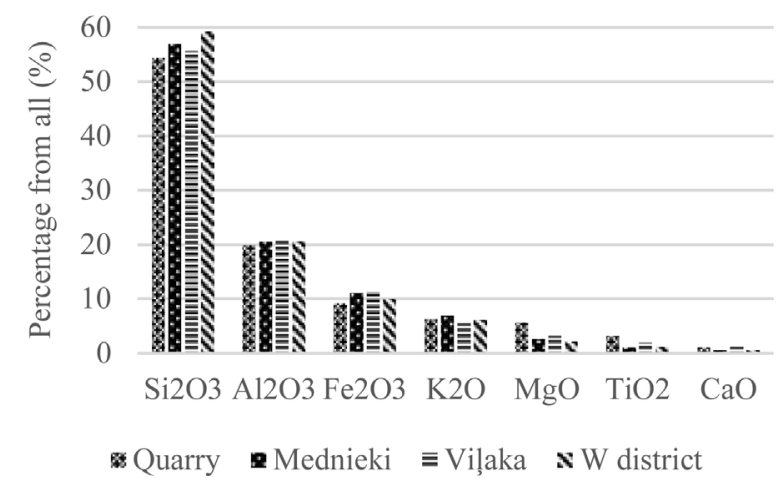

Fig. 7. Comparison of red clay composition.

The most distinctive is the composition of the $\mathrm{Ku}$ prava quarry, South part, where inclusions of small-grain (up to $0.3 \mathrm{~mm}$ ) dolomite grains have been detected. Traditionally, not all rock layers are used in the clay extraction process. Suggestions for using individual layers are given.

There are relatively thick layers of sand between the useful layers of the clay, which, according to total calculations, account for up to $6 \%$ of the corresponding thickness of the clay layers. Devonian sand of the Kuprava clay deposit is a very fine, even size that determines that it is not necessary to sort or sift it before (see Fig. 8).

After the project, the Devonian sand was not intended to be used in the production of ceramic products, but was later used for the leaning of brick clay [13], [14], thus reducing the cost of sand from the project's quarries. 


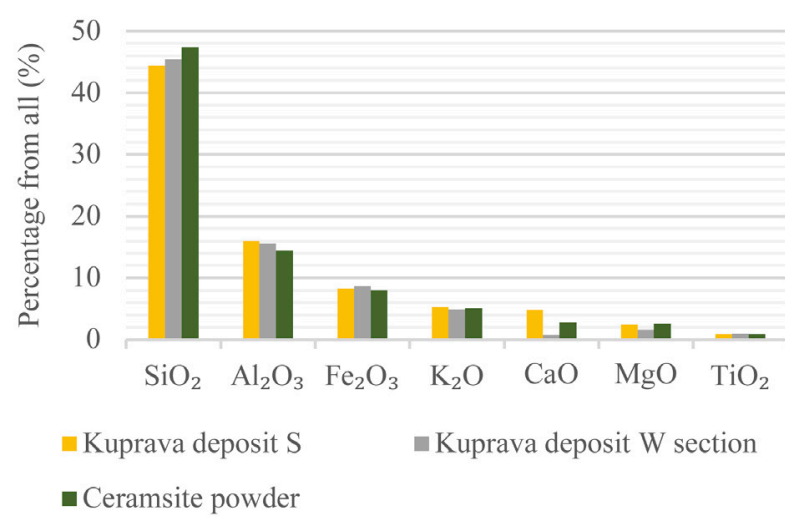

Fig. 8. Comparison of unfired clay and prepared ceramsite composition.

Comparing the composition unfired clays of the Kuprava quarry with composition of ceramsite produced at the Kuprava factory, it can be seen that the $\mathrm{SiO}$ is on average higher than in clay samples. Heavy metal clusters and associated radiation zones in Kuprava is unevenly distributed in the clay layers, in the form of individual islands, leaking inclusions. (Figure 9)

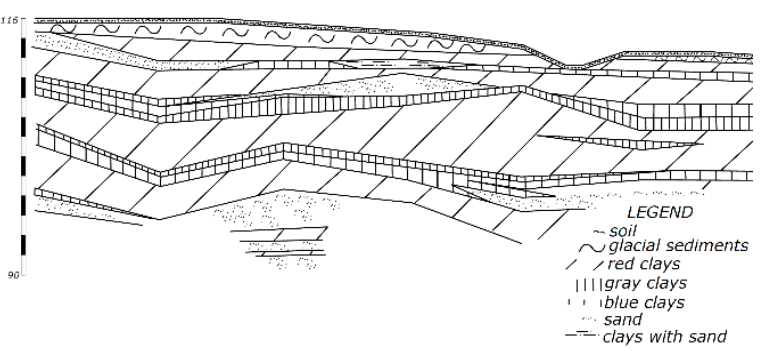

Fig. 9. Profile of Kuprava deposit (example).

The topsoil can be used to improve soils in agricultural lands, gliding after reclamation. Due to its high potassium content, illite clays can be used in agriculture for longterm enrichment with potassium, especially when root crops are grown.

Nowadays, the extraction of dolomite from a thin layer of lime is not economically beneficial due to the small market demand. The use of these dolomites could be the basis for the production of various composite materials, providing sufficient silicon and carbonate in their raw material.

Dolomites have varying degrees of hardness in different areas of the deposit, but most of their hardness and chemical properties correspond to the construction needs of the road base [9]. Because of the need to build driveways in the clay extraction process, the use of the material for these purposes will reduce the amount of unused rock and reduce the cost of constructing access roads to the quarry. This material can also be used to improve local ground roads.
Aleirolite, a bluish clay layer with high $\mathrm{K}$ and $\mathrm{Mg}$ content and coarse-grained calcite inclusions can be used to improve the surrounding sandy soil.

Another possibility of using aleirolite and loam is the production of pellets for road construction, as this process does not require such fatty clays as in Kuprava. As a leaning additive, sand may be used for very plastic clay (up to $0.3 \%$ in diameter if less than $0.3 \mathrm{~mm}$ in diameter) [15].

Practical studies of the extraction of such materials with the sandstone and aleirolites of the Kuprava deposit have not been carried out so far, which could be one of the directions of further research.

As for adsorption properties, each measurement was repeated three times - and in all cases the difference between measurements did not exceed $0,5-0,7 \%$. Given the heterogeneous nature of Clays, the accuracy of these data is fully satisfactory.

Average values of measurements were used for further calculations.

Parallel experiments with mixing time of 5 hours were carried out to determine the effect of the suspension mixing time on adsorption capacity, that showed, that adsorption capacity does increase yet very insignificantly - only by $5 \%$ (for example, from $44,5 \mathrm{mg} / \mathrm{g}$ to $46,8 \mathrm{mg} / \mathrm{g}$ ). That means that mixing time of 30 minutes per sample is sufficient to determine Clay adsorption capacity.

Adsorption isotherms (Fig. 10) were also determined using Methylene Blue. The following initial adsorbate Methylene Blue concentrations were selected: 0,05, 0,1, $0,5,0,7 \mathrm{~g} / 1$.

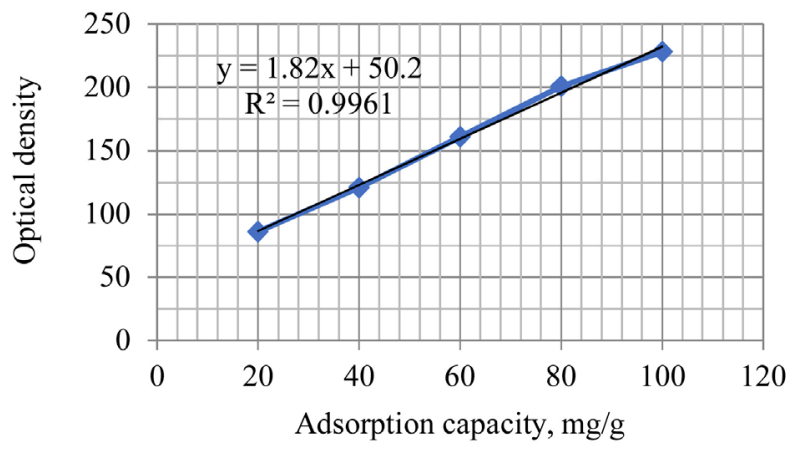

Fig. 10. Graduation curve.

For comparison, adsorption isotherms for two Clay samples from Kuprava clay deposit were determined by analogous methodology. As for Kuprava clay deposit than these were type II adsorption isotherms and they are characterized by high capacity of adsorption - given adsorption concentration $1 \mathrm{~g} / \mathrm{l}$ it does exceed $48 \mathrm{mg} / \mathrm{g}$. Adsorption capacity of Methylene Blue for Kuprava clay deposit sample K1 was 48,8 mg/g and for sample K2 it was 48,4 mg/g (see Fig. 11). Both samples contained I-Illite, Q-Quartz, O-Orthoclase, C-Calcite and K-Kaolinite. 


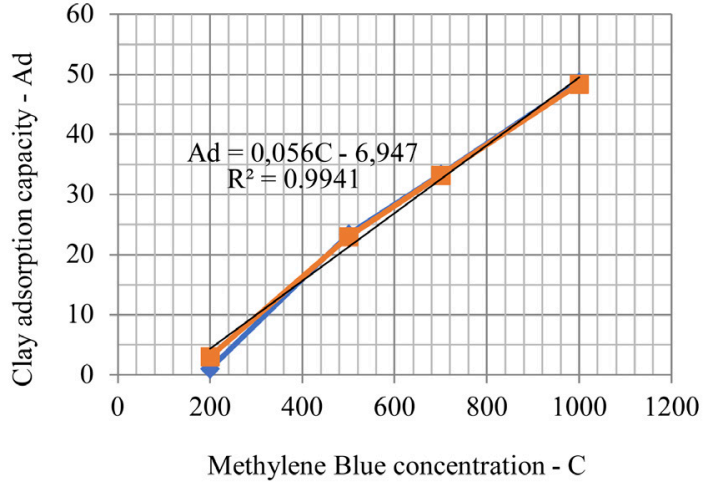

Fig. 11. Kuprava clay sample adsorption capacity base on Methylene Blue concentration.

Further studies on use of Kuprava clay material adsorption properties should be carried out.

\section{Conclusions}

A study on the composition of clay in the area around Kuprava was carried out. Researching the results of the research carried out so far, it is concluded that it is possible to realize the extraction of non-waste minerals in the Kuprava clay deposits - using all the layers of rock to produce different products.

Four potential clay quarry sites have been identified - Mednieki, Vilaka, Kuprava clay ground in Veckuprava and Kuprava clay quarry in Gailava.

\section{ACKNOWLEDGEMENTS}

The author expresses her gratitude to the Institute of Inorganic Chemistry of RTU for the possibility to use the equipment of X-ray diffraction and X-ray spectroscopy and Aija Krūmina for the provided consultations.

\section{REFERENCES}

[1] V. Segliņšs, A. Brangulis, Latvijas zemes dzịlu resursi (Latvian mineral resources). Rīga: Valsts ǵeoloǵijas dienests, 1996 (In Latvian).

[2] L. Maksimova, Viḷaka un tās l̦audis gadsimtu ceḷos (Vilaka and its people on the road for centuries). Rēzekne: Latgales kultūras centra izdevniecība, 2001 (In Latvian).

[3] V. Sorokin, Devon i karbon Pribaltiki (Devon and Carbon in the Baltics). Riga: Zinatne, 1981 (In Russian).

[4] A.U. Itodo, F.W. Abdulrahman, L.G. Hassan, S.A. Maigandi, H.U. Itodo, "Application of Methylene Blue and Iodine Adsorption in the Measurement of Specific Surface Area by four Acid and Salt Treated Activated Carbons". New York: Science Journal, vol. 3, issue 5, 2010.

[5] ASTM C837-09(2014), Standard Test Method for Methylene Blue Index of Clay, West Conshohocken, PA: ASTM International, 2014.

[6] T. A. Zenchenko, Otchet o rezul'tatakh geologo-poiskovykh i razvedochnykh rabot na gliny v Latviyskoy SSR (Report on the results of geological prospecting and exploration for clay in the Latvian SSR). Leningrad: Valsts Ģeolog̣ijas fonds, 1951 (In Russian).

[7] V. M. Kursh, Sopostavleniye dannykh razvedki i razrabotki mestorozhdeniya glin Kuprava (Comparison of exploration data and development of the Kuprava clay deposit). VMNAO Soyuzmorinzhgeologiya. Riga: Valsts Ģeologijas fonds, 1987 (In Russian).

[8] M. Ozols, Tekhnicheskiy otchet o dorazvedke zapadnogo uchastka kar'yera glin "Kuprava" dlya zavoda drenazhnykh trub "Kuprava" (Technical report on the additional exploration of the western section of the "Kuprava" clay quarry for the "Kuprava" drainage pipe factory). Termomaterialproyekt. Riga: Valsts G Geologijas fonds, 1991 (In Russian).

[9] T. A. Ionin, Otchet o predvaritel'noy razvedke glin v Kupravskom mestorozhdenii (Report on preliminary exploration of clays in the Kurava deposit). Valsts Ģeologijas fonds, 1992 (In Russian).

[10] M. Stiebriņa, Pārskats par Mednieku mālu un smilts atradnes geologiskiem izpētes darbiem Balvu rajonā (Review of geological investigations of Mednieki clay and sand deposits in Balvi district). Rīga: Latgiprostroj, 1956 (In Latvian).

[11] K. Jurevics, Pārskats par Jēkabpils keramzīta, Cieceres karbonātisko mālu izpētes un gaiši apdegošo mālu meklēšanas darbiem (Review of Jekabpils Ceramic Clay, Cieceres Carbon Clay Research and Light Burning Clay Search Works). Rīga: Ģeologijas pārvalde, pp. 183-188 (In Latvian).

[12] R. Pakaln, Otchet o rezul'tatakh poiskovykh rabot na dolomity, provedennykh $\vee$ Balvskom rayone Latviyskoy SSR (Report on the results of prospecting work on dolomites conducted in the Balvi region of the Latvian SSR). Riga: LATGIPROGORSTROY, 1956. Valsts Geologijas fonds (In Russian).

[13] Katalog tekhnicheskikh informatsiy po osnovnomu tekhnologicheskomu oborudovaniyu primenyayemomu $\mathrm{v}$ proizvodstve keramzitovogo graviya (Catalog of technical information on the main technological equipment used in the production of expanded clay gravel). Kuibyshev: NIIKERAMZIT, 1980 (In Russian).

[14] Karta tekhnologicheskogo protsessa proizvodstva glinyanogo kirpicha dlya dymovykh trub (Map of the technological process of production of clay brick for chimneys). Kuprava: Latagropromstroy, 1991 (In Russian).

[15] Metodicheskiye rekomendatsii po tekhnologii proizvodstva keramdora dlya primeneniya $\mathrm{v}$ konstruktsiyakh dorozhnykh odezhd (Methodical recommendations on the production technology of road ceramsite for use in pavement structures). Moskva, SOYUZDORNII, 1974 (In Russian). 